\title{
Abraded rock landforms (whalebacks) developed under ice streams in mountain areas
}

\author{
Ian S. Evans \\ Department of Geography, University of Durham, Durham DHI 3LE, England
}

\begin{abstract}
Like many mountain ranges, the Coast Mountains of British Columbia, Canada, have undergone both local and ice-sheet glaciation. Effects of ice sheets are concentrated along major valleys and on adjacent spurs and passes which carried strong flows of diffluent ice. The major valleys are broad glacial troughs with frequent rock basins. Their slopes are broken into rounded, steep-sided bosses (whalebacks) abraded on all sides; they are of the order of $100 \mathrm{~m}$ to $1 \mathrm{~km}$ long, and $10 \mathrm{~m}$ high. In the southern Coast Mountains, the distribution of these whalebacks is consistent with a proposed pattern of former ice streams $1.0-2.1 \mathrm{~km}$ thick, within the Cordilleran ice sheet. They are best developed where geological structures parallel the valley and thus the former ice-flow direction, but they are found on a range of lithologies and some are transverse to structure. The whalebacks provide an impression of glacial streamlining, and occasionally grade into rock drumlins. Roches moutonnées are rare in the major troughs.

It is hypothesised that these whalebacks and rock drumlins develop under ice streams of Greenland or East Antarctic type, sliding rapidly over bedrock and exploiting rock weaknesses to produce streamlined features. Lee slopes are abraded when thick ice suppresses bed separation, even with rapid flow; basal ice of low viscosity would aid this suppression. Water pressures under the ice streams may have remained high, so that lee-side plucking was rare; such plucking is most likely where pressure fluctuates dramatically, and especially when lee cavities under active ice reach atmospheric pressure.
\end{abstract}

\section{INTRODUCTION: MEDIUM-SCALE FORMS OF GLACIAL EROSION}

Studies of forms of glacial erosion most often focus on either narrow (striation, small roche moutonnée) or broad (cirque, trough) scales. Sugden and John (1976, p. 169-173) reviewed a number of positive forms at medium scale, tens and hundreds of metres long or broad: streamlined rock drumlins, more symmetrical whalebacks, truncated roches moutonnées, and flyggbergs which have steep faces either parallel to ice flow or on the lee side. Such features in Sweden have been reviewed by Rudberg $(1973,1988)$, but the conditions which produce one rather than another are far from clear. If they are accepted as true glacial forms, they need to be related to varying conditions at the glacier bed.

Roches moutonnées are abraded up-ice and at the top and sides, but truncated by joint block removal (plucking) on the lee slope which is often roughly stepped. Their length varies from around a metre to approximately a kilometre, where they merge into valley steps. Considering large features in the upper Dee valley, eastern Scotland, hundreds of metres long, Sugden and others (1992) related block removal to high stress gradients and fluctuating water pressures as cavities opened on lee slopes. They hypothesised a late phase of plucking under thin ice during deglaciation. Rea and
Whalley (1994) and others have observed near-contemporary plucking under thin ice.

Rock drumlins and whalebacks show signs of considerable abrasion, but plucking has been absent, or not concentrated on the lee slope, in the later stages of morphogenesis. If bed separation increases the probability of lee plucking, symmetrical or streamlined forms are more likely to develop when separation is absent. Thick ice, low basal ice viscosity and velocity, and low water pressure could help to suppress separation. Constant water pressure might suppress plucking even if separation occurred; this might be achieved if a surface layer of cold ice was too thick to be penetrated by meltwater (personal communication from R. LeB. Hooke, 1995).

Whaleback forms have been observed especially in Sweden (Rudberg, 1973). Rock drumlins (tadpole rocks are found in shale near Syracuse, New York, U.S.A. (Fairchild, 1907, p. 413-416), and in basalt, sedimentary rocks, granite and gneiss in Québec, Canada Dionne, 1987). In central Finland, rock drumlins occur mainly around the edges of drumlin swarms (Glückert, 1973).

Although all three types of medium-scale form are found on various lithologies, it is clear that jointing and other rock structures exert strong control over their form, to the extent that roches moutonnées are very imprecise indicators of ice-flow direction over upland ridges (Gordon, 1981). In some areas of low relief, it seems 
that roches moutonnées reflect limited glacial erosion of earlier rock hills (Lindström, 1988). In mountain valleys, however, ice flow is strongly controlled by relief, and down-valley lineation is dominant. Some medium-scale features are found in transfluent cols which have been deeply eroded (Linton, 1972); they are not eliminated by the progress of erosion.

In this paper, I focus on the high-mountain environment of southwestern British Columbia, Canada. Here symmetrical whaleback forms are characteristic of broad troughs which carried active flows of deep ice. Evans (1990) has suggested that these formed ice streams in the Cordilleran ice sheet. Whalebacks are found on metamorphic, volcanic and intrusive igneous rocks; roches moutonnées are rare in the troughs. Rock drumlins are not common, but one grouping is described. Fast flow is commonly associated with bed separation, yet in these areas this has not led to plucking and the formation of roches moutonnées. Attempts are made here to explain this prevalence of whalebacks.

\section{ICE STREAMS PRESENT AND PAST}

In recent years the formerly vague term "ice stream" has taken on a more precise meaning: a linear zone within an ice sheet flowing at least an order of magnitude faster than the surrounding ice. Ice-stream margins are well defined and heavily crevassed. Ice streams may merge into "outlet glaciers", where mountains on either side protrude above the ice. Most glaciological work has concentrated on ice streams of the Siple Coast, West Antarctica, feeding the Ross Ice Shelf (Bentley, 1987). These have very low surface gradients and are little thicker than surrounding ice. Many other ice streams, for example in East Antarctica (McIntyre, 1985) and Greenland (Echelmeyer and others, 1991), are fixed in bedrock troughs and have steeper gradients; these are of greater relevance here. Since ice streams (including outlet glaciers) are responsible for most of the ice discharged from ice sheets at present, reconstructions of former ice sheets have increasingly recognised the possible importance of former ice streams.

In non-mountainous areas, former ice streams have been recognised by swarms of drumlins oriented differently from those around (Dyke and Morris, 1988). In mountainous areas, reconstruction of former ice flows requires consideration of erosional forms, and the boundaries of former ice streams may not be easy to establish. In this paper, the hypothesis is proposed that abraded streamlined rocks in mountain valleys and passes are characteristic of the former presence of ice streams. They are found in zones where ice was thick and velocities were greater than in intervening areas. Two such areas in British Columbia are now considered.

\section{THE LILLOOET VALLEY INTER-LAKE AREA}

Figure 1 shows the southern Coast Mountains of British Columbia, from Vancouver northwards. Areas of strongly scoured rocks visible on air photographs occur between the heavy lines, and often have sharply defined limits; these define the possible former ice streams. Away from these, in the interior of mountain ranges, cirques and troughs of local glaciation show little effect of overriding ice, although the great majority of summits were covered by the Cordilleran ice sheet (Clague, 1989).

The Lillooet valley is longitudinal to the general northwest-southeast trend of the Coast Mountains and is not an obvious route of outflow of ice from the interior of British Columbia. Nevertheless, the surrounding mountains rise to over $2500 \mathrm{~m}$, and the pattern of striations shows that the valley was followed by major ice flows, with transfluent ice gained from the northeast and lost to the southwest. Both Lillooet Lake (128 m deep) and Harrison Lake $(282 \mathrm{~m}$ ) are deep rock basins surrounded by steep trough sides. The lake surfaces are at 195 and $10 \mathrm{~m}$ altitude, respectively. East of Lillooet Lake, the ice sheet overrode mountains at least $2300 \mathrm{~m}$ high, and whaleback abraded forms are found to $1300 \mathrm{~m}$. At maximum, ice was probably at least $2100 \mathrm{~m}$ thick over the north basin of Lillooet Lake, and $1900 \mathrm{~m}$ thick over the Lillooet valley between these two large lakes.

Downvalley from Lillooet Lake, and down-ice, the valley broadens in a region of strongly ice-scoured rock over $6 \mathrm{~km}$ wide. Spurs either side of the mouths of Rogers Creek and Gowan Creek were strongly modified by overriding ice; Figure 2a illustrates whaleback forms on the steep eastern bank of the Lillooet, above Skookumchuck. On the southwest side of the Lillooet valley north and south of the mouth of Snowcap Creek, streamlining of bedrock was pronounced up to $1300 \mathrm{~m}$ altitude: streamlined forms are clear up to $1700 \mathrm{~m}$ around Fire Mountain, but the larger features are below $1100 \mathrm{~m}$.

Mapped in Figure 3 are 239 streamlined forms whalebacks and four rock drumlins - in the area between Skookumchuck and the head of Harrison Lake. This figure is based on three sheets of the provincial 1:20000 map, and only features affecting two or more $20 \mathrm{~m}$ contours are included. These are in areas identifiable as scoured rock on air photographs. Many of these features are incomplete "tails" or "noses", and many are benches falling away only on the valley side, so it is difficult to define their height. It was more feasible to measure their length, except for a few whose limits at one end are unclear as they merge into the valley side. Measured lengths range upward from $140 \mathrm{~m}$, since smaller features are difficult to recognise on these maps. There is a tail of high length values; hence, for Table 1, medians were used to summarise lengths for different lithologies.

Larger features (around $400 \mathrm{~m}$ long) are on the Early Cretaceous volcanic-related rocks of the Brokenback Hill Formation (Gambier Assemblage: sometimes metamorphosed to greenschist grade) (Lynch, 1990a, b), especially the slate and lapilli tuff; andesite forms are somewhat smaller (Table 1). The Cenozoic granodiorite intrusion east of Fire Mountain (Fig. 3) is not so conspicuously streamlined, but despite its quite different structure it does have numerous elliptical abraded forms a few hundred metres long. Undated metavolcanics and gneiss, restricted here to the east bank of the Lillooet valley, have somewhat smaller whalebacks. The smallest forms are on diorite and volcanic conglomerate, which may be the hardest rocks, but many of the diorite forms 


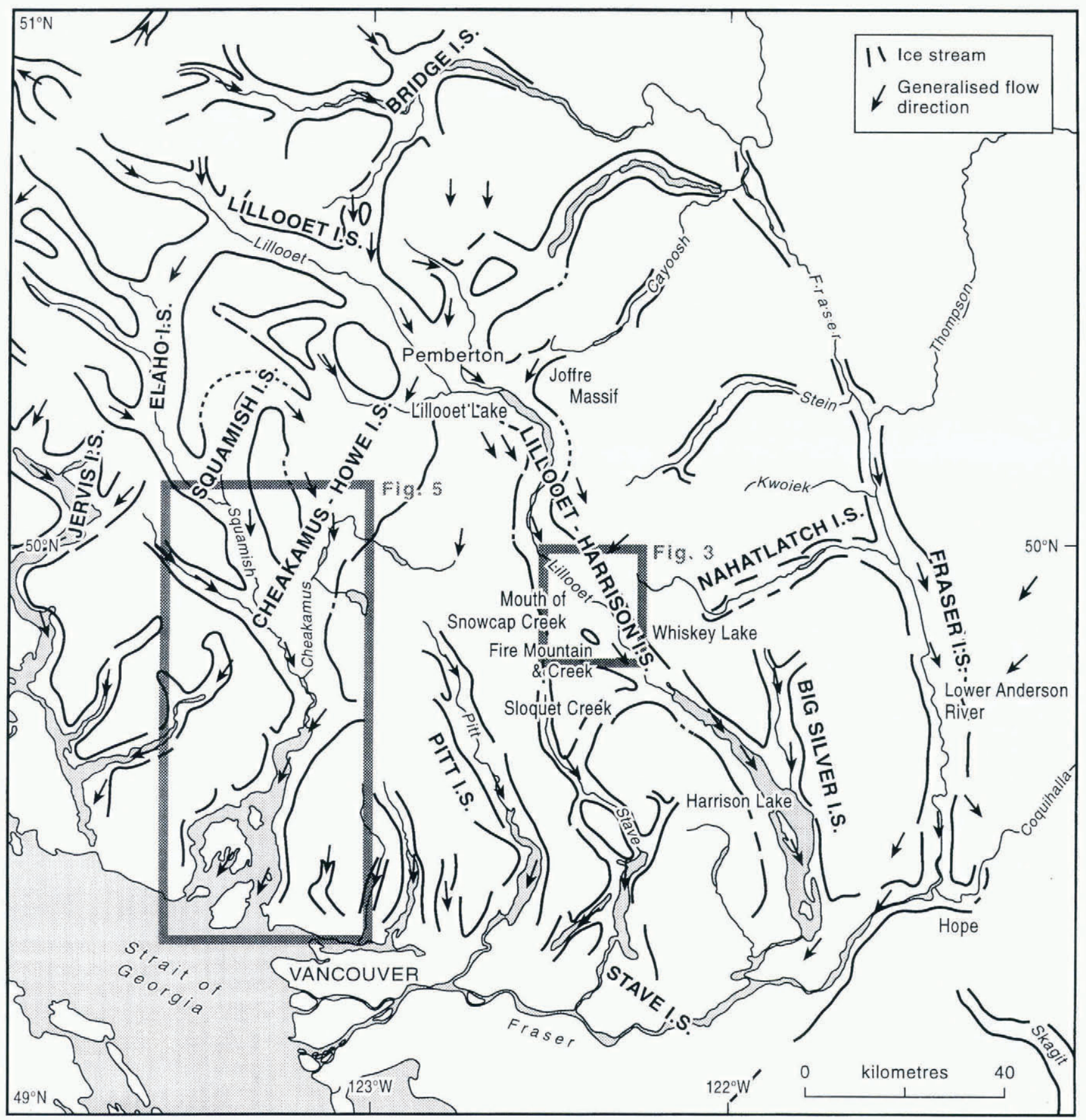

Fig. 1. The southern Coast Mounlains of British Columbia, showing study areas (Figs 3 and 5) and inferred ice streams in the former Cordilleran ice sheet.

are around $1600 \mathrm{~m}$ altitude on a mountain north of Snowcap Creek and thus developed under thinner ice.

Figure ta provides a section crossing some features with a relief of $100 \mathrm{~m}$, though the more clearly glacially shaped ridges are smaller and some of them (e.g. on the northeast bank) are not captured by the $20 \mathrm{~m}$ contour interval. This and the other two profiles are essentially in bedrock. One rock drumlin on the west bank north of Fire Mountain consists mainly of andesite; another is granodiorite with a tail of lapilli tuff. Drumlinization of bedrock was facilitated by structures within the Gambier Assemblage, striking broadly parallel to the Lillooet valley. Narrow linear troughs are up to $2 \mathrm{~km}$ long on slate, but are found also, with the same trend, on the
Cenozoic granodiorite intrusion. They do not follow mapped faults or boundaries, but may relate to late structures.

The Gambier volcanics and slates form valley-side benches where streamlined forms are closely spaced. Forms on the granodiorite are more rounded, fairly large, and well spaced. The features on gneiss seem well spaced on Figure 3, but there are smaller intervening whalebacks, seen in Figure 2b. The section in Figure 4b, $20 \mathrm{~km}$ downstream from that in Figure $4 \mathrm{a}$, crosses this area east of Whiskey Lake; most ridges have less than $10 \mathrm{~m}$ relief, but some whalebacks show up as steps in the profile.

Down-ice, the northern part of Harrison Lake is in a deep trough. It broadens out at the mouth of Big Silver 


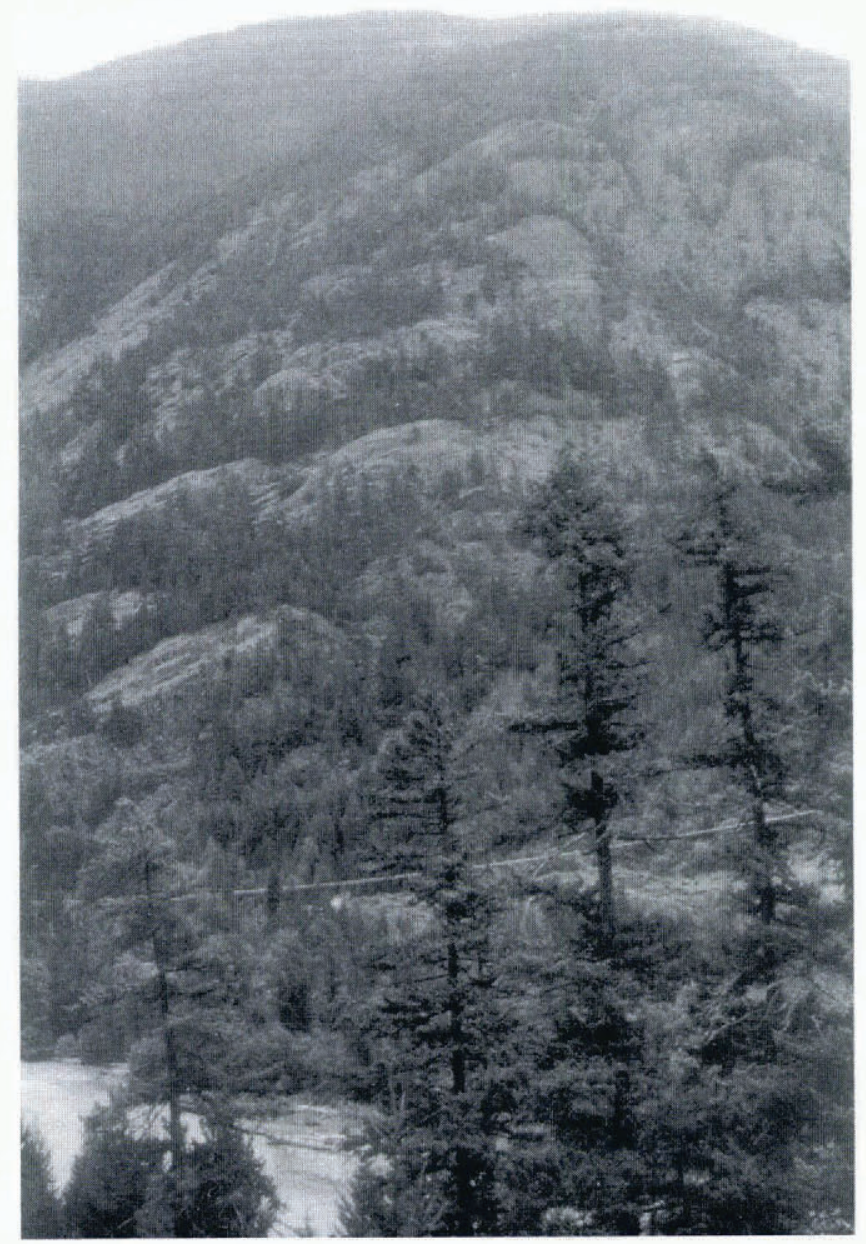

a

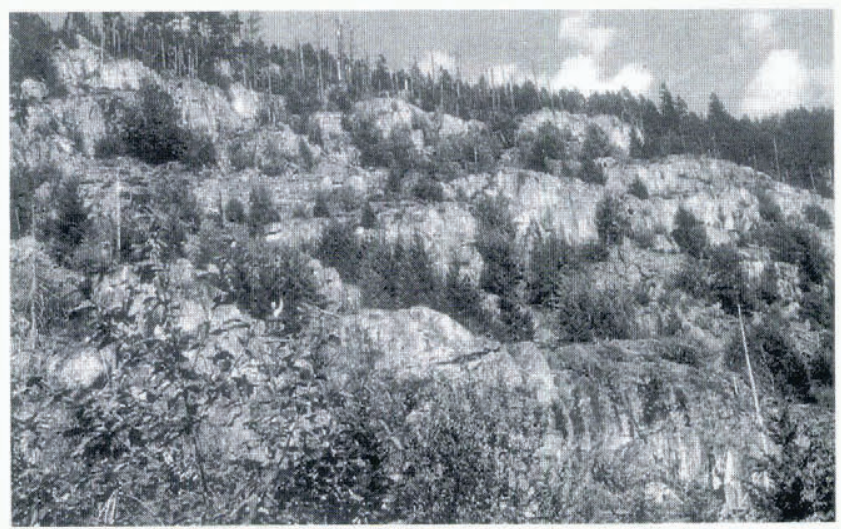

b

Fig. 2. (a) Whaleback rocks in granodiorite, andesite and slate on a ridge-end on the northeast slope of the Lillooet River valley, above the village of Skookumchuck, opposite the mouth of Snowcap Creek. Ice flowed from left to right. (b) A series of whaleback rocks in gneiss and diorite on a logged slope east of Whiskey Lake (Fig. 3). Ice flowed from left to right. These smaller features are less evident under forest cover, and only a few are captured from maps with a $20 \mathrm{~m}$ conlour interval.
Creek, a valley in which erosion has exploited faults and the foliation of schists. Around the southern part of Harrison Lake, ice exploited the foliation of Mesozoic volcanics, sandstones and schists. Streamlined rocks are found on both banks, but are longest and most pronounced on two large islands (Long and Echo) and on the Cascade Peninsula.

\section{THE GHEAKAMUS VALLEY AND HOWE SOUND}

In the heart of the southern Coast Mountains, ice congestion in the Pemberton area was sufficient that in addition to flow down the Lillooet valley, large quantities of ice took a more direct route to the coast, up the Green River valley and down the Cheakamus (Fig. 1). Narrowing in the Whistler area, this proposed Cheakamus-Howe Ice Stream was reinforced by ice from the Squamish and Ashlu valleys, from the Garibaldi area and from the Tantalus Range, and it eroded the fjord of Howe Sound where water depths currently reach $290 \mathrm{~m}$. Ice overrode the adjacent Goat Ridge $(1762 \mathrm{~m}$ ) but probably not the summit of Sky Pilot Mountain (2031 m): hence, maximum ice thickness in this part of Howe Sound was at least $2050 \mathrm{~m}$, plus the thickness of later sediment in the Sound. The Cheakamus valley floor near Daisy Lake Fig. 5) is at $360 \mathrm{~m}$ altitude, and erratics and striae are found at $2190 \mathrm{~m}$ just to the southeast (Mathews, 1958), so the ice thickness reached at least $1830 \mathrm{~m}$ in the middle of the valley.

Rocks in the valley around Whistler (Fig. 5 ) are icescoured, but not very lineated. Around Callaghan Creek, erosional streamlining reaches the surrounding ridges, but is especially marked from $1250 \mathrm{~m}$ down to the valley mouth near $500 \mathrm{~m}$ altitude. Whalebacks tend to parallel foliation in the Early Cretaceous Gambier Assemblage rocks of volcanic and sedimentary origin. The section in Figure $4 \mathrm{c}$ crosses the $11 \mathrm{~km}$ breadth of valley most affected; whalebacks have a relief of up to $100 \mathrm{~m}$, and some are separated by closed depressions in bedrock. Down-ice around Daisy Lake the whalebacks are transverse to structures in diorite and quartz-diorite. An orthophotomap sheet 3 of B.C. Special Project 80.019T.0) shows these streamlined rocks especially well. Only the larger ones are shown in Figure 5.

Streamlining is very pronounced over a width of $5 \mathrm{~km}$ around the Cheakamus Canyon, where several whalebacks in quartz diorite have a relief of over $100 \mathrm{~m}$. Farther south near Squamish, Stawamus Chief is the largest of several spectacular whalebacks in granodiorite, rising $620 \mathrm{~m}$ on the trough side and $320 \mathrm{~m}$ on the other. It is a compound feature $2.3 \mathrm{~km}$ long.

Howe Sound broadens out on an extensive outcrop of Gambier rocks. On Gambier Island the pronounced glacial streamlining is clearly transverse to rock strike as mapped by Roddick and Woodsworth (1979). On Bowen Island, it is oblique to the strike of the Jurassic Bowen Group (greenstone). A width of $20 \mathrm{~km}$ was strongly affected by streamlining at the mouth of Howe Sound, near West Vancouver.

Throughout the route of the proposed ice stream, glacially abraded, lineated rocks mainly of whaleback form are found on a variety of rock types. Their sides 


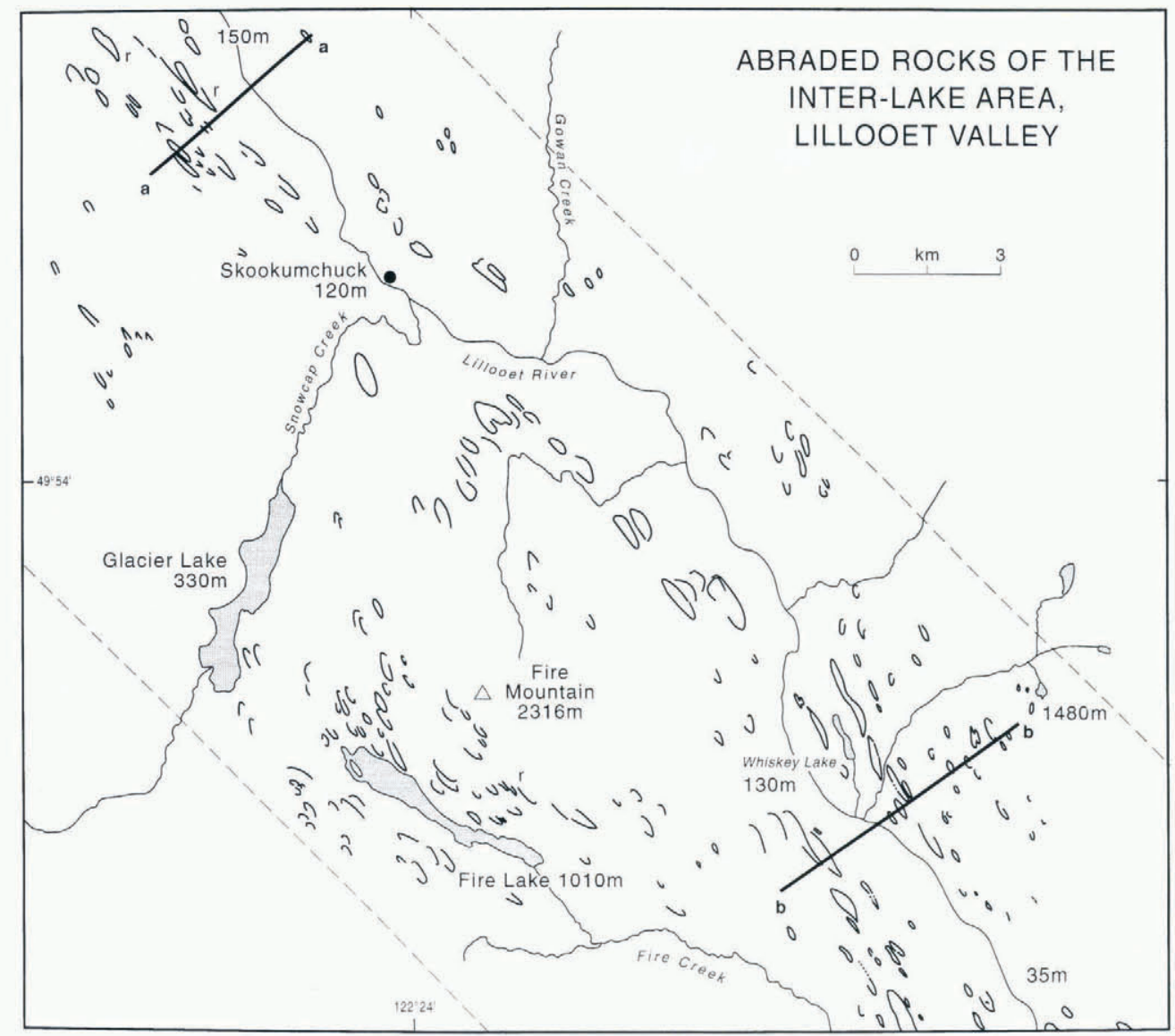

Fig. 3. Map of streamlined rocks in the inter-lake area of Lillooel River valley. $a-a$ and $b-b$ are the lines of cross-sections in Figure 4 .

follow structures where these are oriented close to glacier flow, but are transverse to structures that are at high

Table 1. Lengths ( $m$ ) of streamlined abraded rocks (whalebacks and rock drumlins) in the Lillooet valley, on I : 20000 map sheets 92G.089, .098 and .099. Rock types ordered by median length of feature

\begin{tabular}{|c|c|c|c|c|}
\hline Rock type & Number & Median & $\begin{array}{l}\text { Mini- } \\
\text { mum }\end{array}$ & $\begin{array}{l}\text { Maxi- } \\
\text { mum }\end{array}$ \\
\hline Lapilli tuff $(\mathrm{G})$ & 17 & 420 & 220 & $>760$ \\
\hline Slate $(\mathrm{G})$ & 32 & 400 & 160 & 1160 \\
\hline Granodiorite" & 43 & 330 & 140 & 1720 \\
\hline $\begin{array}{l}\text { Volcaniclastic sandstone } \\
\text { (G) }\end{array}$ & 48 & 320 & 170 & 1300 \\
\hline Metavolcanics* & 11 & 300 & 200 & 940 \\
\hline Andesite $(\mathrm{G})$ & 42 & 290 & 100 & 1300 \\
\hline Gneiss* & 24 & 265 & 140 & 570 \\
\hline $\begin{array}{l}\text { Diorite (Late Jura.- } \\
\text { Early Cret.) }\end{array}$ & 13 & 240 & 120 & 520 \\
\hline Volcanic conglomerate & 9 & 220 & 150 & 340 \\
\hline
\end{tabular}

(G) Gambier Assemblage, mainly Brokenback Hill Formation; Early Cretaceous.

Age uncertain or varied.

Geology is taken from a map by Lynch (1990b). angles to flow. Similar whalebacks and streamlining are found, on a smaller scale, along the other ice streams proposed in Figure 1.

\section{ICE-STREAM GRADIENTS AND VELOCITIES}

Ice streams within these mountains would not have been like Ice Streams A to E, which feed the Ross Ice Shelf from West Antarctica. The latter have very low surface gradients and driving stresses, yet flow rapidly because of low basal friction due in part to deforming wet sediment Bentley, 1987). Rather, Cordilleran mountain ice streams would have been like those of East Antarctica described by McIntyre (1985). These are $66-86^{\circ} \mathrm{S}$ and most are over $10 \mathrm{~km}$ wide and $2-3 \mathrm{~km}$ thick. There is a steep step in the ice surface where flow converges at the ice-stream head and accelerates to over $100 \mathrm{ma}^{-1}$. Ice surface gradients below this are of the order of 0.01 .

At $69^{\circ} \mathrm{N}$ in West Greenland, Jakobshavns Isbre is an ice stream some $85 \mathrm{~km}$ long, $6 \mathrm{~km}$ wide and up to $2600 \mathrm{~m}$ thick: inland it slopes at 0.01 , increasing to 0.03 near the grounding zone (Echelmeyer and others, 1991). It flows in a deep bedrock trough, at steady speeds, e.g. $1 \mathrm{~km} \mathrm{a}{ }^{1}$ $50 \mathrm{~km}$ inland where ice is $2500 \mathrm{~m}$ deep, $5 \mathrm{~km}$ wide and surface gradient is 0.012 ; there is no significant seasonal variation in speed or in basal water pressure. This may well be the best modern-day analogy to glacial maximum conditions in the southwestern Coast Mountains. Most of the ice is cold (rapidly advected from high altitudes), but 


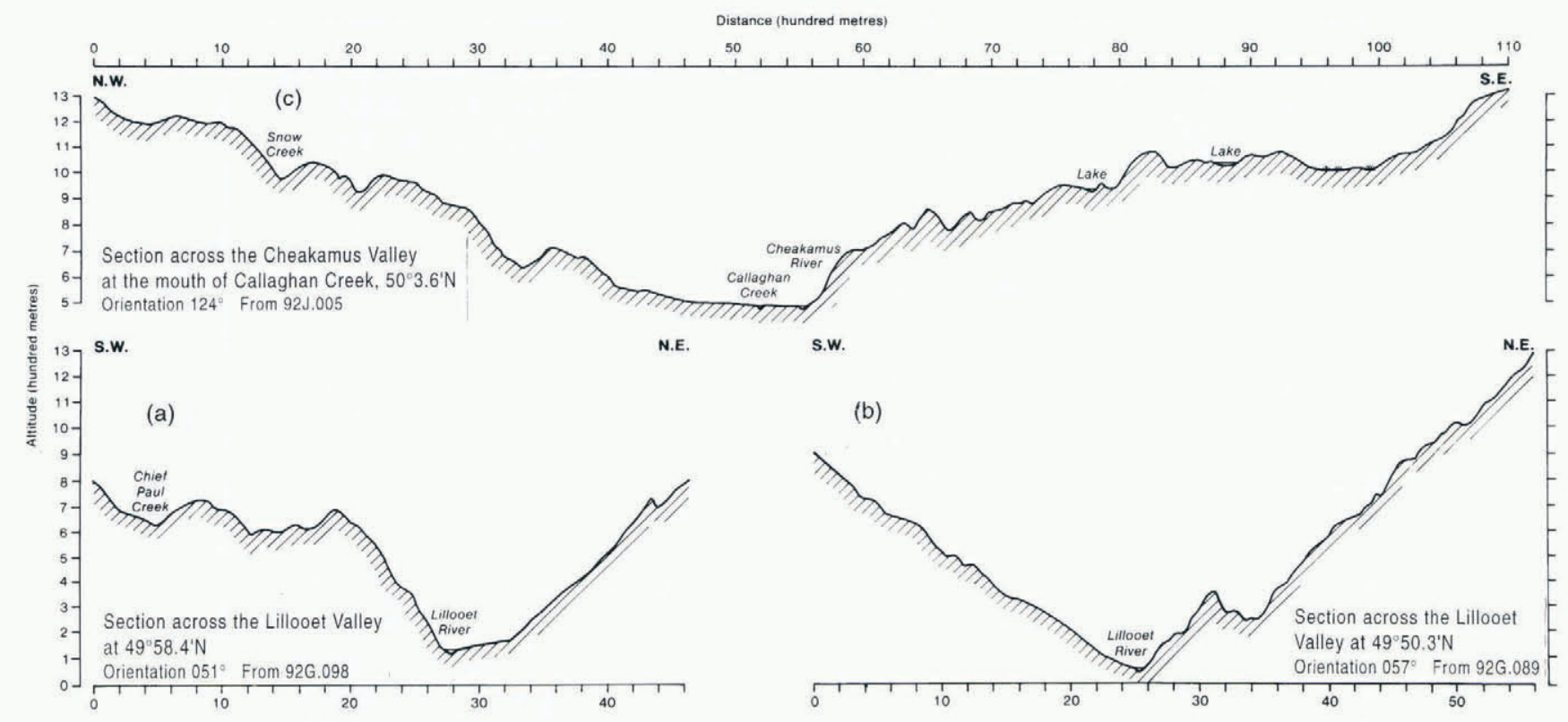

Fig. 4. Sections across the Lillooet ( $a$ and b) and Cheakamus ( $c$ ) valleys, in areas with conspicuous streamlined hills and rocks. Constructed from $20 \mathrm{~m}$ contours on recent 1:20000 scale maps published by the Province of British Columbia.

there is a basal temperate layer which deforms rapidly and thickens toward the centre of the trough (Iken and others, 1993).

At $50^{\circ} \mathrm{N}$ near the Pacific Ocean, mass balances today are very active. Even during glacial maxima, turnover was probably much greater than in the East Antarctic, Svalbard and West Greenland today, and ice temperatures would also have been higher. Neither of these differences would have prevented the formation of ice streams in the Coast Mountains. According to Booth's (1987) reconstruction, which does not take ice streams into account, at the Cordilleran ice sheet maximum some 15000 years ago ice gradients in the Cheakamus-Howe Sound area would have been about 0.006 , considerably less than in the lobes down-ice. At an earlier stage with ice calving at the mouth of Howe Sound near Vancouver, some 20000 years ago according to Clague (1989, fig. 1.23 , the ice-stream gradient could have been 0.02 . On the Lillooet-Harrison Ice Stream, a surface slope from $2600 \mathrm{~m}$ near Pemberton to $1700 \mathrm{~m}$ at the south end of Harrison Lake would be around 0.01 .

Thicknesses in both cases would have reached the order of $2 \mathrm{~km}$ at the maximum phase, and less at other times. Durations are uncertain, but the glacial maximum is thought to have been short-lived, with deglaciation by about 11000 radiocarbon years ago (Souch, 1989). According to Booth (1987), the Puget Lobe entered Washington State for only 4500 years.

The Lillooet valley ice fed into the Puget Lobe, whereas the Cheakamus-Howe ice probably reached the Juan de Fuca Lobe of the Cordilleran ice sheet. In reconstructing the Puget Lobe sector at maximum, Booth (1987) suggested an ELA of $1225 \mathrm{~m}$ in Washington State around $48^{\circ} \mathrm{N}$, with an ice velocity there of $660 \mathrm{ma}^{-1}$, of which $98 \%$ was by basal sliding (or sediment deformation). Average velocities in the accumulation areas further north were considerably less, but were still estimated at hundreds of metres per year by Booth, without considering the concentration of discharge into ice streams. The proposed ice streams would therefore have been in "fast-flow" mode (Clarke, 1987) at the icesheet maximum, and may have flowed even faster during the build-up phase when ice-surface gradients were steeper. There is very little evidence of sediment on these valley sides: the little sediment present today is concentrated in the middle of the valleys. Hence, movement over the valley sides would have been by ice deformation and sliding over bedrock.

\section{DISCUSSION}

Despite the clear importance of structure, this alone cannot be responsible for the distinction between rock drumlins, whalebacks and roches moutonnées. A glaciological hypothesis is required. Roches moutonnées have not been developed under thick, fast moving ice in the areas described above. The asymmetry of roches moutonnées may develop with lee separation under thin glacier ice, as noted on Deeside in Scotland by Sugden and others (1992). Plucking depends on ice flow giving differential pressure on up-ice and lee slopes. It is proposed here that asymmetric (lee-side) plucking requires either air-filled lee cavities, as under thin ice, or lee cavities where water pressure varies as in the model of Hooke (1991) and Iverson (1991).

A further proposal is that, under thick ice, lee plucking is unlikely and whaleback forms develop. Whalebacks can develop under ice a few hundred metres thick, but are larger where ice was 1 or $2 \mathrm{~km}$ thick. Extending flow in the accumulation zone is likely to bring boulders to the glacier bed, encouraging abrasion rather than plucking (personal communication from H. Röthlisberger, 1995). Abrasion on lee slopes requires that cavities close for part of the time. If both plucking and lee abrasion are infrequent or slow processes compared with lateral abrasion, tapered lee tails may develop and cavities may be eliminated, giving rock drumlins. Asymmetric 


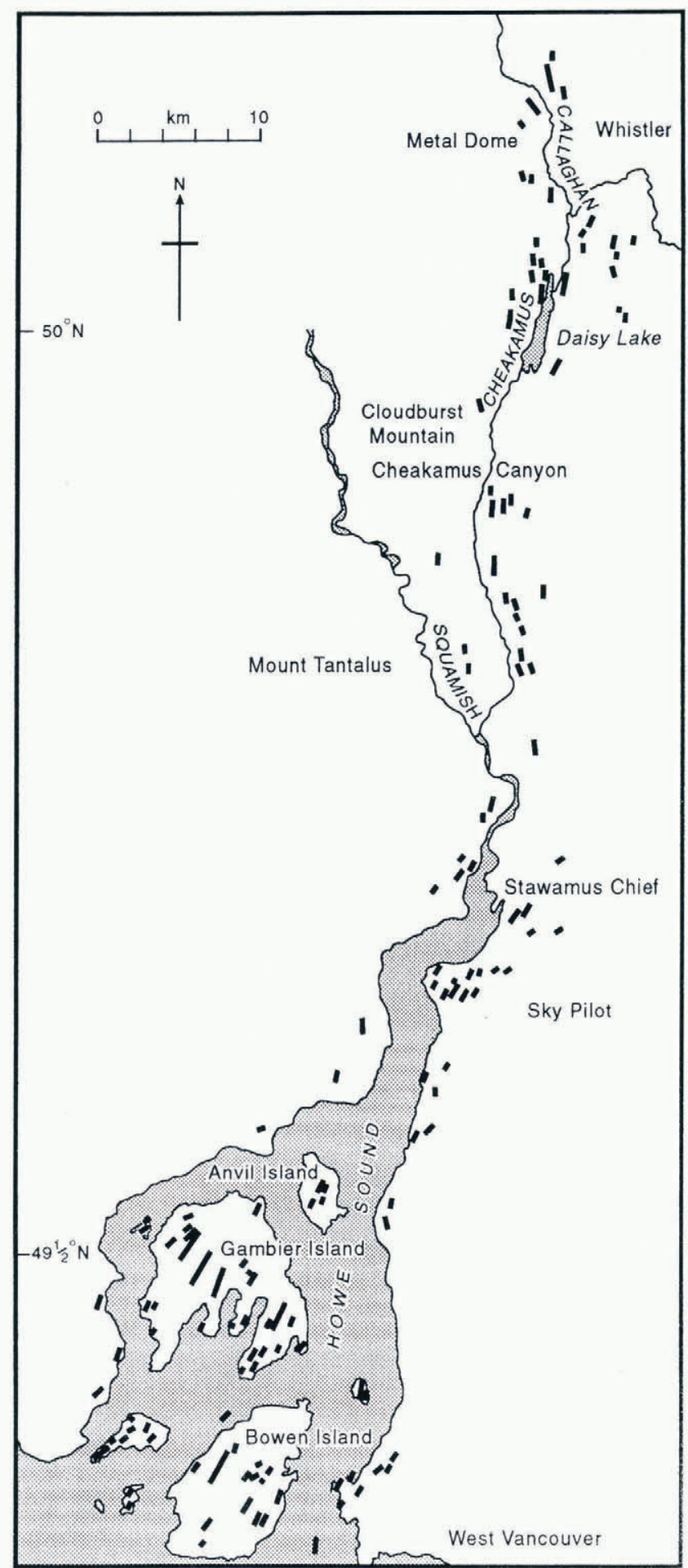

Fig. 5. Long streamlined hills (shown by heavy bars) in the Cheakamus-Howe Sound area, just north of Vancouver.

plucking might be expected locally during deglaciation. This depends on the rate and nature of deglaciation and on the topography. During rapid deglaciation, ice velocity may decline before ice thins sufficiently for airfilled cavities, or cavities with fluctuating pressure, to develop.

\section{CONCLUSION}

In high mountain areas inundated by ice sheets, rapid flow will be concentrated in major valleys with appro- priate orientations. This was the case in the Cheakamus and Lillooet valleys of southwestern British Columbia. The erosional forms developed there, under deep ice deforming and sliding rapidly over bedrock, are mainly whalebacks without pronounced asymmetry. Rock drumlins are sometimes found, but completely asymmetric roches moutonnées are rare.

It is proposed that symmetrical whaleback forms are characteristically developed under deep, rapidly flowing ice streams. Abrasion affects the whole form, including the lee side. This has implications for the nature of lee separation and water pressure variations. Low pressure on the lee side may be required, at least intermittently, to permit asymmetric plucking and thus the development of roches moutonnées. The extent to which this pressure must be low in absolute or relative terms requires investigation.

Further information is also required on the distribution of roches moutonnées, whalebacks and rock drumlins in relation to probable former ice thicknesses and velocities. Although ice thickness is not as important in abrasion as Boulton (1974) proposed, it may be much more important in relation to plucking.

Finally it is noted that the resolution of current models of ice sheets does not permit good representation of ice streams a few kilometres wide, as in many mountain areas. This is particularly unfortunate where most ice discharge is concentrated in ice streams. Some of the consequences of ignoring ice streams are discussed by Iken and others (1993).

These ideas should be applicable to Norway and Patagonia, as well as the Coast Mountains of British Columbia. Flows in the major valleys of the Alps may have had comparable effects.

\section{ACKNOWLEDGEMENTS}

Field-work and visits to air-photo libraries were supported by a Canadian Studies Research Award and by grants from Durham University Staff Research Fund. I am grateful also to Maps B.C. and the B.C. Ministry of Forests for access to their air-photo collections. Comments by G. Boulton, N. Cox, R. LeB. Hooke, O. Sigurdsson and $\mathrm{J}$. Warburton led to a number of improvements in this paper. The figures were drawn by S. Allan, A. Corner and D. Hume of the departmental drawing office.

\section{REFERENCES}

Bentley, C. R. 1987. Antarctic ice streams: a review. J. Geophys. Res. 92 B9), 8843-8858

Booth, D. B. 1987. Timing and processes of deglaciation along the southern margin of the Cordilleran ice sheet. In Ruddiman, WV. F. and H. E. Wright, Jr, eds. North America and adjacent oceans during the last deglaciation. Boulder, CO, Geological Society of America, 71-90. Geology of North America K-3.

Boulton, G. S. 1974. Processes and patterns of glacial erosion. In Coates, D. R., ed. Glacial geomorphology. Binghamton, NY, State University of New York, 41-87.

Clague, J.J. 1989. Quaternary geology of the Canadian Cordillera. In Fulton, R.J., ed. Quatemary geology of Canada and Greenland. Ottawa. Geological Survey of Canada, 15-96. Geology of Canada 1, Geology of North America K-1.

Clarke, G. K. C. 1987. Fast glacier flow: ice streams, surging and tidewater glaciers. J. Geophys. Res., 92 B9), 8835-8841. 
Dionne, J. -C. 1987. Tadpole Rock (rocdrumlin): a glacial streamline moulded form. In Menzies, J. and J. Rose, eds. Drumlin Symposium. Rotterdam, A. A. Balkema Publishers, 149-159.

Dyke, A. S. and T.F. Morris. 1988. Drumlin fields, dispersal trains, and ice streams in Arctic Canada. Can. Geogr., 32(1), 86-90.

Echelmeyer, K., T.S. Clarke and W.D. Harrison. 1991. Surficial glaciology of Jakobshavns Isbre, West Greenland: Part I. Surface morphology. 7. Glaciol., 37 (127), 368-382.

Evans, I.S. 1990. Ice streams in the Cordilleran ice sheet, southwestern British Columbia. Program with Abstracts, 15th Joint Annual Meeting, G.AC/MAC, 16-18 May 1990, Vancouver, B.C. Geological Association of Canada, Mineralogical Association of Canada and Canadian Geophysical Union, 37.

Fairchild, H. L. 1907. Drumlins of central western New York. N.1. Stale Mus. Bull., 111, 391-443.

Glückert, G. 1973. Two large drumlin fields in central Finland. Fennia $120,1-37$.

Gordon, J.E. 1981. Ice-scoured topography and its relationships to bedrock structure and ice movement in parts of northern Scotland and West Greenland. Geogr. Ann., 63A 1 - 2), 5565 .

Hooke, R. LeB. 1991. Positive feedbacks associated with erosion of glacial cirques and overdeepenings. Geol. Soc. Am. Bull., 103 8), 1104 1108.

Iken. A.. K. Echelmever, W. Harrison and M. Funk. 1993. Mechanisms of fast flow in Jakobshavns Isbrx, West Greenland: Part I. Measurements of temperature and water level in deep boreholes. 7 . Glaciol., 39 (131), 15-25.

Iverson, N.R. 1991. Potential effects of subglacial water-pressure fluctuations on quarrying. J. Glaciol., 37 (125), 27-36.

Lindström, E. 1988. Are roches moutonneés mainly preglacial forms? Geogr. Ann., 70A $(4), 323-331$.
Linton, D. L. 1972. The forms of glacial erosion. In Embleton, C. ed. Glaciers and glacial erosion. London, Macmillan, 149-172.

Lynch, J. G. V. 1990a. Geology of the Fire Lake Group, southeast Coast Mountains, British Columbia. Geol. Surv. Can. Pap. 90-1E, 197-204.

Lynch, J. G. V. 1990b. Geology of the Glacier Lake map (92G/16). Geol. Surv. Can. Open File Rep. 2203.

McIntyre, N.F. 1985. The dynamics of ice-sheet outlets. F. Glaciol., 31 108), 99-107.

Mathews, W.H. 1958. Geology of the Mount Garibaldi map-area, southwestern British Columbia, Canada. Part II. Geol. Soc. Am. Bull., 69 (2), $179-198$.

Rea, B. R. and W. B. Whalley. 1994. Subglacial observations from Oksfjordjokelen, north Norway. Earth Surface Processes and Landforms, 19 (7), 659-673.

Roddick, J. A. and G. Woodsworth. 1979. Geology of Vancouver West half (92G) and the mainland part of Alberni (92F). Geol. Surv. Can. Open File Rep. 611.

Rudberg, S. 1973. Glacial erosion forms of medium size - a discussion based on four Swedish case studies. Z. Geomorphol., Supplementband $17,33-48$.

Rudberg, S. 1988. Gross morphology of Fennoscandia - six complementary ways of explanation. Geogr. Ann., 70A 3), 135-167.

Souch, C. 1989. New radiocarbon dates for early deglaciation from the southeastern Coast Mountains of British Columbia. Can. J. Earth Sci., $26(10), 2169-2171$.

Sugden, D. E. and B.S. John. 1976. Glaciers and landscape; a geomorphological approach. London, Edward Arnold.

Sugden, D. E., N. Glasser and C. M. Clapperton. 1992. Evolution of large roches moutonnées. Geogr. Ann., 74A 2-3), 253-264. 